\title{
PENINGKATAN PENDAPATAN KELOMPOK PETERNAK KELINCI MELALUI NILAI TAMBAH PRODUKSI
}

\author{
INCREASED REVENUE RABBIT BREEDERS GROUP THROUGH VALUE ADDED \\ PRODUCTION
}

\author{
Nia Kurniasih Suryana \\ Jurusan Agribisnis, Fakultas Pertanian \\ Universitas Borneo Tarakan \\ E-mail: zlynia@gmail.com
}

\begin{abstract}
ABSTRAK
Usaha Peternakan kelinci memiliki peluang untuk meningkatkan pendapatan dan kesejahteraan masyarakat. Semakin tingginya populasi kelinci, tentunya akan menjadi kendala jika tidak diimbangi dengan kegiatan pemasarannya. Untuk itu upaya meningkatkan nilai tambah dari produk kelinci harus dilakukan dengan mengoptimalkan teknologi pengolahan hasil ternak. Tempat pelaksanaan pengabdian kepada masyarakat di kelompok peternak "Flora Mandiri" dan "Lady Valentin" di Kecamatan Tarakan Utara dan Kecamatan Tarakan Barat Kota Tarakan selama 3 bulan. Tujuan dari kegiatan pengabdian kepada masyarakat ini adalah meningkatkan pengetahuan dan keterampilan peternak dalam pengolahan hasil ternak dan limbah kelinci. Solusi yang ditawarkan melalui kegitan penyuluhan dan pelatihan. Target dan luaran yang diharapkan meningkatkan pengetahuan peternak sehingga peternak memahami bagaimana cara budidaya kelinci, pengolahan hasil dan limbah ternak kelinci, serta meningkatkan keterampilan peternak sehingga peternak dapat mengolah hasil produk ternak menjadi beberapa produk olahan serta dapat membuat pupuk dari limbah kelinci. Hasil kegiatan menunjukan adanya perubahan perilaku lebih baik yang meliputi aspek pengetahuan, keterampilan dan sikap peternak dalam mengolah hasil produksi kelinci.
\end{abstract}

Kata Kunci : Ternak Kelinci, Pengolahan Hasil Ternak, Limbah Ternak

\begin{abstract}
The rabbit farm business has an opportunity to increase the income and welfare of the community. The higher population of rabbits, of course, will be an obstacle if not offset by marketing activities. For that effort to increase the added value of rabbit products must be done by optimizing the technology of livestock processing. The place of service to the community in breeders group "Flora Mandiri" and "Lady Valentin" in North Tarakan Subdistrict and Tarakan Barat Subdistrict Tarakan City for 3 months. The purpose of community service activities is to improve knowledge and skills of farmers in the processing of livestock and rabbit wastes. Solutions are offered through training and training activities. The target and expected outcomes of the Rabbit Breeders Group "Flora Mandiri" and "Lady Valentin" is to increase the knowledge of farmers so that farmers understand how to cultivate rabbits, rabbit processing and rabbit wastes, and improve the skills of farmers so that farmers can process livestock products into some processed products can make fertilizer from rabbit waste. The results of the activities showed a better behavior change that includes aspects of knowledge, skills and attitude of farmers in processing rabbit production.
\end{abstract}

Keyword : Livestock Rabbit, Animal Product Processing, Waste Livestock 


\section{(1) PENDAHULUAN}

Kota Tarakan mempunyai letak geografis yang strategis, sehingga memiliki peran dan kedudukan yang penting baik bagi lingkup provinsi maupun nasional. Kota Tarakan terletak di bagian utara pulau Kalimantan yang sebelumnya secara administratif masuk wilayah Provinsi Kalimantan Timur, namun sejak disahkannya UndangUndang Nomor 2012 pada tanggal 16 November 2012, Kota Tarakan merupakan bagian Provinsi Kalimantan Utara yang merupakan hasil pemekaran dari Provinsi Kalimantan Timur.

Pembangunan Kota Tarakan diarahkan pada pengembangan berbagai sektor, salah satu sektor yang cukup penting adalah sektor pertanian dan peternakan. Pembangunan peternakan merupakan bagian dari suatu totalitas kinerja agribisnis, khususnya sub sistem usaha ternak dengan keluaran berupa produksi primer ternak. Sasaran pembangunan peternakan di Kota Tarakan diarahkan pada peningkatan ketahanan pangan produk ternak, peningkatan nilai tambah dan daya saing produk ternak serta peningkatan kesejahteraan peternak. Untuk mencapai hal tersebut harus memberdayakan potensi peternakan yang dimiliki.
Jenis ternak yang diusahakan di Kota Tarakan terdiri dari sapi, kerbau, kuda, babi, ayam, itik dan kelinci (Badan Pusat Statistik Kota Tarakan, 2016). Beberapa tahun terakhir ternak kelinci mendapatkan cukup perhatian dari masyarakat maupun pemerintah, karena memiliki potensi yang sama baiknya dengan jenis ternak lainnya. Permintaan pasar akan daging kelinci semakin meningkat, fenomena itulah yang mendorong peternak mengembangkan usaha ternak kelinci. Namun demikian berternak kelinci memang tidak mudah. Agar kelinci yang diternakkan dapat berkembang dengan baik, diperlukan perawatan yang tepat.

Salah satu kelompok yang mengembangkan ternak kelinci adalah Kelompok Ternak "Flora dan Fauna Mandiri" dan "Lady Valentine" yang berada di wilayah Kecamatan Tarakan Utara dan Kecamatan Tarakan Barat Kota Tarakan. Jumlah anggota kelompok masing-masing sebanyak 20 orang. Saat ini populasi kelinci yang dipelihara anggota kelompok tersebut kurang lebih ada 250 kelinci. Ada dua jenis kelinci yaitu kelinci pedaging dan kelinci peliharaan, namun yang banyak diusahakan adalah jenis kelinci pedaging.

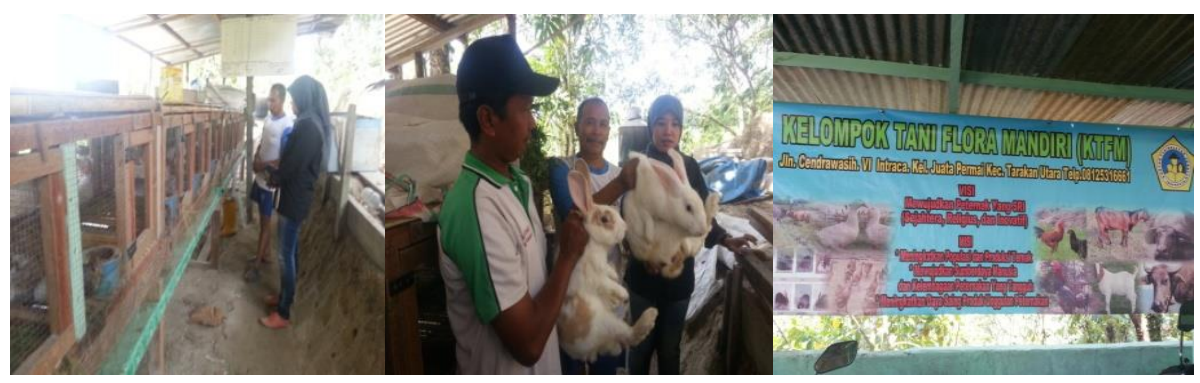

Gambar 1. Kelompok Peternak Kelinci "Flora dan Fauna Mandiri” dan "Lady Valentine" di Kota Tarakan

Dalam upaya pengembangan usaha ternak kelinci, pemerintah Kota Tarakan melalui Dinas Peternakan, Perikanan dan Tanaman Pangan memberikan fasilitasi berupa pengadaan bibit atau pengadaan anakan lepas untuk pembesaran, pakan ternak dan alat pembuatan pakan, serta obat-obatan. 
Pemeliharaan kelinci yang dilakukan oleh anggota kelompok masih sederhana. Bentuk kandang tertutup terbuat dari kayu. a. Ada dua tipe kandang, yaitu tipe postal dan tipe baterai. Kandang tipe postal adalah kandang untuk menempatkan menempatkan $b$. beberapa ekor kelinci sekaligus. Digunakan sebagai kandang perkembangbiakkan, yaitu c. untuk membesarkan anak-anak kelinci setelah disapih dari induknya.Sedangkan kandang tipe baterai adalah kandang yang didesain untuk satu ekor kelinci per kandang. Biasanya digunakan untuk pembesaran ternak kelinci potong. Ukuran kandang untuk kelinci $60 \times 40 \times 40 \mathrm{~cm}$, atau disesuaikan dengan ukuran bobot tubuh ras kelinci yang digunakan.

Pemasaran kelinci masih terbatas, hanya beberapa rumah makan di Kota Tarakan yang menyediakan menu yang berasal dari daging kelinci. Kelinci dijual oleh peternak dalam bentuk hidup. 1) Budidaya kelinci

Konsumen lebih banyak dari rumah tangga 2) Pengolahan hasil termak kelinci baik untuk dikonsumsi maupun untuk 3) Pengolahan limbah ternak kelinci dipelihara. Semakin tingginya populasi 2. Pelatihan

kelinci, tentunya akan menjadi kendala jika tidak diimbangi dengan kegiatan pemasarannya. Untuk itu upaya meningkatkan nilai tambah dari produk kelinci harus dilakukan dengan mengoptimalkan teknologi pengolahan hasil ternak.

\section{(2) METODE}

Berdasarkan permasalahan yang dihadapi oleh kelompok ternak kelinci "Flora dan Fauna Mandiri" dan "Lady Valentine" maka ada beberapa solusi yang ditawarkan yaitu :

\section{Penyuluhan}

Sebagai sebuah tindakan praktis, penyuluhan merupakan upaya-upaya yang dilakukan untuk mendorong terjadinya perubahan prilaku pada individual, kelompok, komunitas, ataupun masyarakat agar mereka mau,dan mampu menyelesaikan permasalahan yang dihadapi (Amanah, 2007). Tujuan ini dapat dicapai apabila para petani dalam masyarakat melakukan langkah-langkah sebagai berikut :

Better farming, mengubah cara usahataninya dengan cara yang lebih baik.

menguntungkan.

Better living, hidup lebih baik

Penyuluhan yang diberikan kepada anggota kelompok ternak kelinci "Flora dan Fauna Mandiri" dan "'Lady Valentine" bertujuan untuk meningkatkan pengetahuan tentang pengolahan hasil ternak dan pemanfaatan limbah ternak kelinci. Metode penyuluhan dilakukan secara kelompok dengan melakukan pertemuan, serta diskusi. Media yang dipergunakan media terproyeksi berupa gambar dan atau tulisan lewat slide. Materi yang disampaikan dalam penyuluhan meliputi: $\begin{array}{rrr}\text { Menurut } & \text { Never } & \text { Ending } \\ \text { Transfusing - } & \text { Application } & \text { Training }\end{array}$ (NET-at), pelatihan adalah kegiatan belajar dan praktek untuk sesuatu tujuan baik, dilakukan secara berulang-ulang dan terus-menerus untuk meningkatkan kemampuan (continuously and never end) manusia, dan fitrahnya. Pelatihan merupakan proses pembelajaran yang memungkinkan seseorang dapat melakukan suatu pekerjaan sesuai dengan standar.

Pelatihan yang dilakukan untuk anggota kelompok ternak kelinci "Flora dan Fauna Mandiri" dengan praktek secara langsung cara pengolahan hasil ternak dan limbahnya. Pelatihan yang diberikan meliputi :

Praktek cara membuat bakso dari daging kelinci.

Praktek cara membuat nuget dari daging kelinci. 
3) Praktek cara membuat topu karage dari daging kelinci.

4) Praktek cara membuat pupuk dari kotoran kelinci

\section{Pendampingan}

Kegiatan

pendampingan dimaksudkan mendampingi sekaligus memantau perkembangan usahanya dari apa yang telah diperoleh dalam kegiatan Program Pengabdian pada Masyarakat ini. Pendampingan dilakukan dengan tujuan kegiatan yang ada tetap berjalan dengan hasil akhirnya peningkatan pendapatan dan kesejahteraan peternak.

$$
\text { Partisipasi mitra dalam }
$$

pelaksanaan kegiatan ini dimulai dari perencanaan sampai pelaksanaan kegiatan. Materi dalam penyuluhan dan pelatihan berdasarkan pada kebutuhan kelompok peternak kelinci. Untuk lebih jelasnya partisipasi mitra dalam pelaksanaan pengabdian kepada masyarakat dapat dilihat pada tabel 2 berikut :

Tabel 2. Kegiatan dan Partisipasi Mitra

\begin{tabular}{|c|c|c|}
\hline No & Kegiatan & Partisipasi Mitra \\
\hline 1 & Penyuluhan & $\begin{array}{l}\text { a. Ikut menentukan materi penyuluhan sesuai kebutuhan. } \\
\text { b. Berperan aktif dalam pelaksanaan kegiatan penyuluhan. } \\
\text { c. Aktif dalam proses belajar dengan memahami materi yang disampaikan. }\end{array}$ \\
\hline 2 & Pelatihan & $\begin{array}{r}\text { a. Ikut merencanakan pelaksanaan pelatihan (menentukan waktu dan tempat, } \\
\text { persiapan alat dan bahan dll) } \\
\text { b. Berperan aktif dalam pelaksanaan pelatihan. } \\
\text { c. Mempraktekan hasil pelatihan. }\end{array}$ \\
\hline 3 & Pendampingan & $\begin{array}{r}\text { a. Berperan aktif dalam monitoring dan evaluasi kegiatan. } \\
\text { Bekerjasama dengan penyuluh untuk mengaplikasikan hasil pelatihan dalam } \\
\text { usahanya. }\end{array}$ \\
\hline
\end{tabular}

\section{(2) HASIL DAN PEMBAHASAN}

\section{A. Profil Sasaran}

Sasaran dari kegiatan kemitraan masyarakat ini adalah kelompok ternak Flora Mandiri dan Lady Valentine. Kelompok tersebut berada di Kecamatan Tarakan Utara dan Kecamatan Tarakan Barat.

Kelompok ternak kelinci Flora Mandiri berdiri Tahun 2013, seiring waktu kegiatan kelompok ternak kelinci tersebut terus berkembang, bukan hanya dibidang ternak, tapi sudah mulai dibidang perikanan dan pertanian (hotikultura), sehingga pada tahun. Pada Tahun 2017 berubah nama menjadi kelompok tani Flora dan Fauna Mandiri, dengan identitas kelompok sebagai berikut :

Nama kelompok : Flora dan Fauna Mandiri

\section{Berdiri Tahun : 16 Juli 2017}

Produksi : kelinci, hortikultura (lombok, tomat, jagung manis), ikan lele, cincau hijau, jeruk lemon.
Kelompok Flora dan Fauna Mandiri membina bidang ; peternakan kelinci, perikanan, budidaya ikan lele dan ikan nila serta produksi pupuk organic (padat dan cair). Jumlah anggota kelompok sebanyak 16 orang dengan luas lahan masing-masing ratarata 1 ha.

Komoditi unggulan kelompok tersebut meliputi ternak kelinci, cincau hijau, jeruk lemon, Lombok dan ubi kayu. Sumber keuangan dalam menjalankan kegiatan kelompok sebagian besar berasal dari iuran anggota. Untuk tahun 2017 program kerja yang disusun meliputi pengembangan kandang kelinci, perbanyakan budidaya cincau hijau, serta perbanyakan jeruk lemon.

Kelompok Lady Valentine merupakan kelompok Konsep Rumah Pangan Lestari (KRPL), terbentuk Tahun 2017 memiliki anggota kelompok sebanyak 20 orang. Kelompok ini membina bidang peternakan kelinci dan 
budidaya tanaman hortikultura. Rogram kerja yang dibuat untuk Tahun 2017 meliputi pengembangan ternak kelinci, pengembangan budidaya hortikultur untuk pemanfaatan pekarangan dan pembuatan pupuk organic.

\section{B. Penyuluhan}

Penyuluhan adalah proses pembelajaran bagi pelaku utama serta pelaku usaha agar mau dan mampu menolong dan mengorganisasikan dalam mengakses informasi informasi pasar, teknologi, permodalan dan sumber daya lainnya sebagai upaya untuk meningkatkan produktivitas, efisiensi usaha, pendapatan dan kesejahteraannya serta meningkatkan kesadaran dalam pelestarian fungsi lingkungan hidup. Penyuluhan bertujuan untuk merubah perilaku baik aspek pengetahuan, keterampilan maupun sikap.
Penyuluhan yang dilakukan dalam kegiatan kemitraan masyarakat ini bertujuan untuk memberikan pengetahuan kepada kelompok peternak kelinci Flora dan Fauna Mandiri dan Lady Valentine agar tau bagaimana mengolah hasil produk kelinci menjadi beberapa produk makanan serta tau bagaimana cara mengolah limbah kelinci menjadi pupuk organic dalam bentuk padat maupun cair.

Penyuluhan dilaksanakan pada tanggal 30 Oktober 2017 bertempat di Rumah Kreatif BUMN (RKB) Kota Tarakan, jumlah peserta yang hadir sebanyak 20 orang yang merupakan perwakilan dari anggota kelompok ternak Flora dan Fauna Mandiri dan Lady Valentine, penyuluh Kota Tarakan dan mahasiswa.

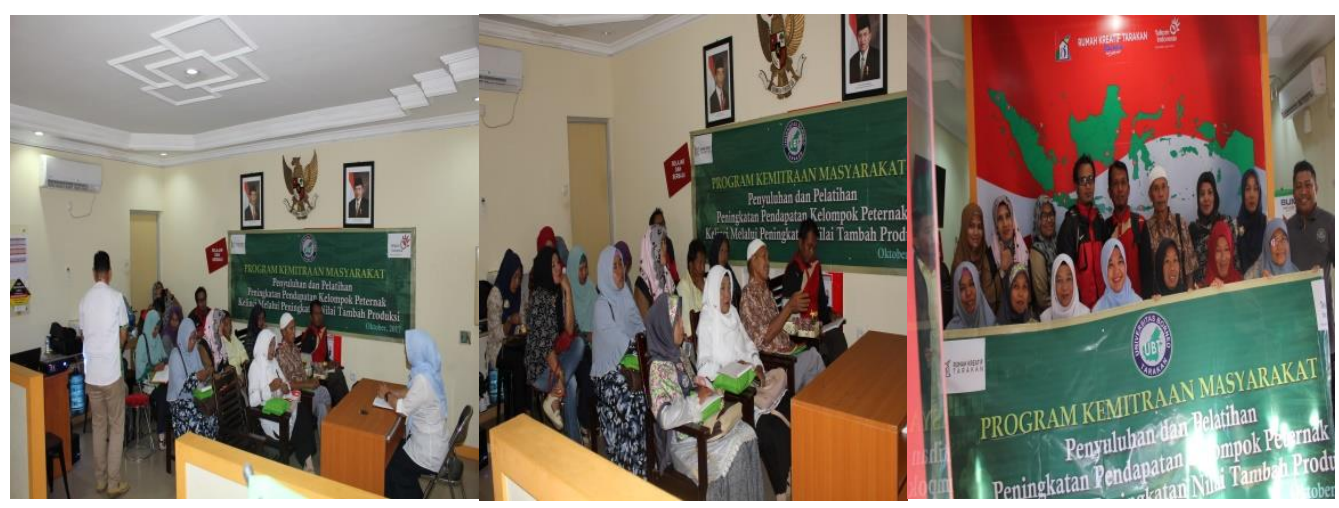

Gambar 2. Proses Pelaksanaan Penyuluhan

Materi penyuluhan yang disampaikan adalah tentang pengolahan hasil produksi kelinci menjadi bakso, nugget, karage dan patty burger, serta tentang cara pembuatan pupuk organic dari limbah kelinci. Hal yang harus diperhatikan dalam pengolahan daging adalah kesehatan dan keamanan, yang meliputi; cuci tangan, menggunakan sarung tangan, menggunakan penutup kepala, menggunakan celemek, menggunakan sepatu karet dan menyediakan bak desinfektan. Selain itu untuk konsistensi rasa maka harus diperhatikan pula pemilihan kualitas bahan, penimbangan, proses produksi, packaging, dan storage .

Pengolahan daging kelinci menjadi bakso, nugget, topu karage dan patty burger diawali dengan mempersiapkan perlengkapan dan alat serta membuat pasta daging kelinci. Perlengkapan dan alat yang digunakan adalah; timbangan digital, grinder, mixer, food prosesor, nugget mulder, kompor, panic, dandangan, deep prayer/wajan, vacuum packing, freezer, sealer dan sendok 
makan. Berikut table produksi pasta daging kelinci.

Tabel 3. Tabel Produksi Pasta Daging Kelinci

\begin{tabular}{|r|r|r|r|}
\hline \multicolumn{1}{|c|}{ Bahan Baku } & Satuan (gram) & Harga (Rp/kg) & Jumlah (Rp) \\
\hline Daging kelinci giling & 1500 & 85.000 & 127.000 \\
\hline Tepung Tapioka & 150 & 7.000 & 1.050 \\
\hline Telur & 55 & 35.000 & 1.650 \\
\hline Pengenyal makanan & 13 & 130.000 & 1.690 \\
\hline Garam & 35 & 7.000 & 245 \\
\hline Kaldu ayam & 3 & 40.000 & 120 \\
\hline Es Batu & 400 & 3.000 & 120 \\
\hline Merica bubuk & 1 & 190.000 & 190 \\
\hline Bawang Putih & 50 & 80.000 & 4.000 \\
\hline Lain-lain & & & 177.535 \\
\hline TOTAL & 2.207 & & \\
\hline
\end{tabular}

Sumber: Rumah Kreatif BUMN Tarakan, 2017

Berdasarkan table 3 di atas biaya produksi yang diperlukan dalam membuat pasta kelinci sejumlah Rp.177.535, sehingga harga per produksi untuk per kg sebesar Rp.80.500. Bahan pasta ini merupakan bahan dasar untuk membuat bakso kelinci, nuget, topu karage dan burger. Cara membuat pasta kelinci yaitu dengan mencampurkan semua bahan dan dimasukan kedalam food processor.

1. Bakso Kelinci

Tabel 4. Bahan Pembuatan Bakso Kelinci

\begin{tabular}{|r|r|r|r|}
\hline Bahan Baku & Satuan (gram) & Harga (Rp/kg) & \multicolumn{1}{|c|}{ Jumlah (Rp) } \\
\hline Pasta daging kelinci & 2.207 & 80.500 & 177.664 \\
\hline Air & $5.000 \mathrm{ml}$ & 1.000 & 5.000 \\
\hline Biaya produksi & & & 36.533 \\
\hline TOTAL & & & 219.197 \\
\hline
\end{tabular}

2. Nuget

Tabel 5. Bahan Pembuatan Nuget

\begin{tabular}{|r|r|r|r|}
\hline Bahan Baku & Satuan $($ gram $)$ & Harga $(\mathrm{Rp} / \mathrm{kg})$ & Jumlah $(\mathrm{Rp})$ \\
\hline Pasta daging kelinci & 2.207 & 80.500 & 177.664 \\
\hline Air & $5.000 \mathrm{ml}$ & 1.000 & 5.000 \\
\hline Tepung Panir & 500 & 40.000 & 20.000 \\
\hline Bread Crumb & 2.000 & 40.000 & 80.000 \\
\hline Sayuran & $500 \mathrm{pcs}$ & 30.000 & 15.000 \\
\hline Minyak Goreng & $1000 \mathrm{ml}$ & 17.000 & $17 / 000$ \\
\hline Putih Telur & 500 & 35.000 & 17.500 \\
\hline Biaya produksi & & & 66.432 \\
\hline TOTAL & & & 398.597 \\
\hline
\end{tabular}

3. Topu Carage

Tabel 6. Bahan Pembuatan Topu Karage

\begin{tabular}{|l|l|l|l|} 
Bahan Baku & Satuan (gram) & Harga (Rp/kg) & Jumlah (Rp) \\
\hline
\end{tabular}




\begin{tabular}{|r|r|r|r|}
\hline Pasta daging kelinci & 2.207 & 80.500 & 177.664 \\
\hline Air & $5.000 \mathrm{ml}$ & 1.000 & 5.000 \\
\hline Tepung Protein Sedang & 2.000 & 8.000 & 16.000 \\
\hline Pollo Croccante Powder & 120 & 180.000 & 21.000 \\
\hline Tahu & $100 \mathrm{pcs}$ & 1.000 & 100.000 \\
\hline Minyak Goreng & $1000 \mathrm{ml}$ & 17.000 & 17.000 \\
\hline Biaya produksi & & & 67.333 \\
\hline TOTAL & & & 403.997 \\
\hline
\end{tabular}

4. Patty Burger

Tabel 7. Bahan Pembuatan Burger

\begin{tabular}{|r|r|r|r|}
\hline \multicolumn{1}{|c|}{ Bahan Baku } & Satuan (gram) & Harga (Rp/kg) & Jumlah (Rp) \\
\hline Daging giling kelinci & 1.260 & 80.500 & 101.430 \\
\hline Merica & 25 & 60.000 & 1500 \\
\hline Bubuk pala & 25 & 35.000 & 875 \\
\hline Garam & 35 & 7.000 & 245 \\
\hline Tepung Tapioka & 2.000 & 8.000 & 16.000 \\
\hline Tepung Beras & 2.000 & 8.000 & 16.000 \\
\hline Telor & 500 & 35.000 & 17.500 \\
\hline Biaya produksi & & & 30.710 \\
\hline TOTAL & & & 184.260 \\
\hline
\end{tabular}

5. Pupuk Organik

Alat dan bahan pembuatan pupuk dari urine kelinci :

1. Urin kelinci 1 liter

2. EM4 $10 \mathrm{ml}$

3. Molase/Tetes tebu/Gula merah $10 \mathrm{ml}$

4. Wadah dan botol yang memiliki tutup Alat dan bahan pembuatan pupuk dari Feses kelinci :

1. Feses kelinci

2. Tricoderma

3. Plastik Hitam

\section{Pelatihan}

Pelatihan dilaksanakan bertujuan untuk meningkatkan keterampilan sasaran, dengan cara mendemonstrasikan langsung cara pembuatan beberapa produk olahan daging kelinci seperti bakso kelinci, nuget, topu karage dan burger serta cara pengolahan kotoran kelinci baik berupa feses maupun urine kelinci.
Pelatihan dilaksanakan pada tanggal 1 November 2017, dengan cara demonstrasi langsung. Peserta sangat antusias sekali mengikuti pelatihan, hal ini dapat terlihat dari keterlibatan mereka dalam membantu proses pengolahan. Berikut beberapa dokumentasi pada saat proses pengolahan dan hasilnya.

1) Bakso Kelinci

Cara membuat bakso kelinci :

- $\quad$ Rebus air dalam panci sampai mendidih, setelah itu kecilkan api

- Siapkan adonan (pasta kelinci) dan bentuk menjadi bulatan sesuai selera, masukkan ke dalam panci yang berisi air panas (jangan terlalu panas,karena bentuk bakso tidak bulat maksimal kalau terlalu panas airnya).

- Bulatan bakso akan mengembang dan berubah warna menjadi coklat keabuan, kemudian rebus lagi selama 10-15 menit. 
- Tiriskan dan bakso siap untuk dimakan atau diolah menjadi berbagai jenis menu makanan atau disimpan.Menyiapkan air dan didihkan.

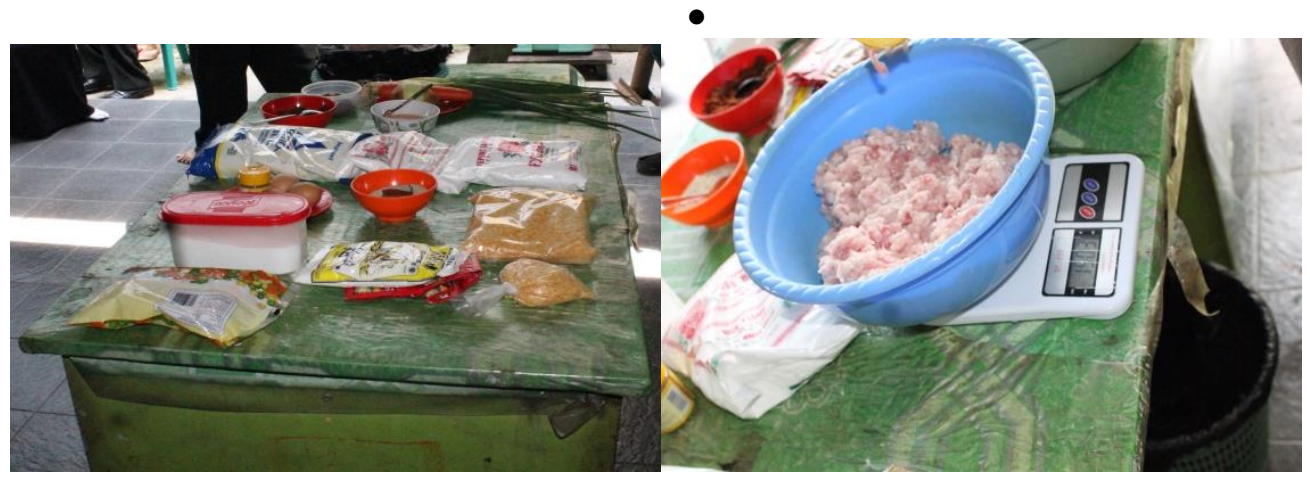

Gambar 2. Bahan Pembuatan Pasta Kelinci

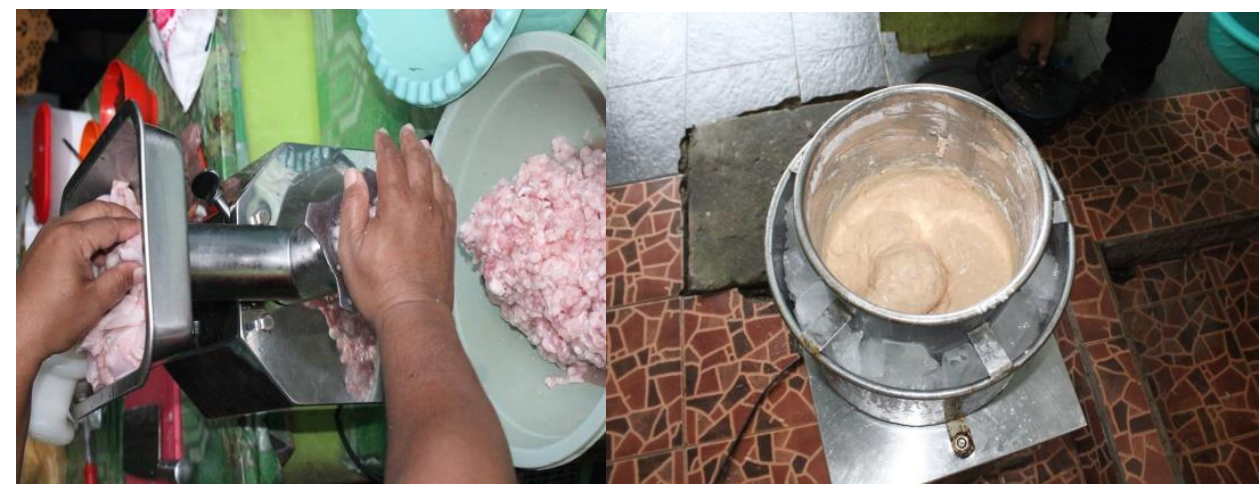

Gambar 3. Proses Penggilingan Pasta Kelinci
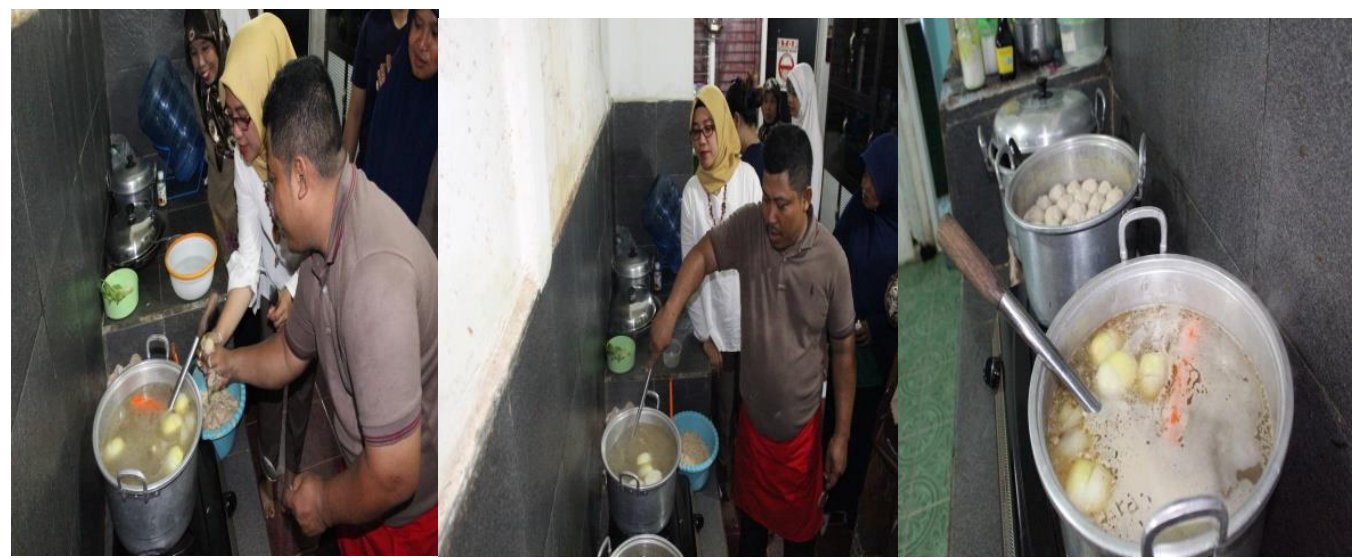

Gambar 4. Proses Pembentukan Bakso dan Pembuatan Kuah Bakso

2) Nuget Kelinci

Cara membuat nuget kelinci :

- Pasta kelinci ditambahkan tepung roti dan sayuran

- Cetak adonan dan dikukus selama 10 menit

- Adonan yang telah dikukus potong kotak sesuai selera
- Nugget dilumuri dengan tepung roti dan dilakukan penggorengan awal (digoreng setengah matang).

- Kemas nugget dalam vakum dan simpan pada suhu rendah. Jika akan dimakan nuget digoreng selama empat menit. 


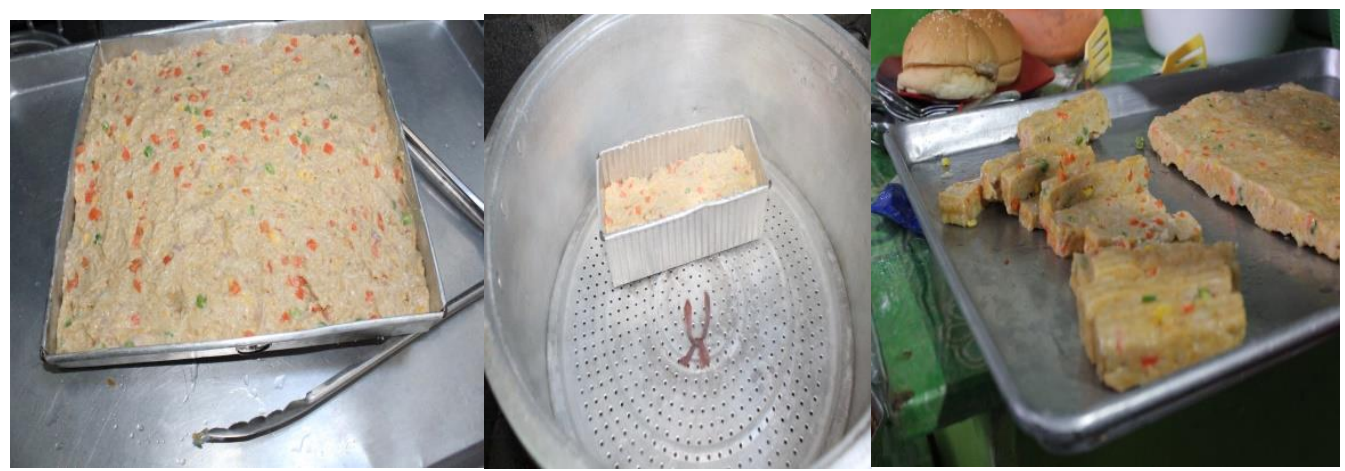

Gambar 5. Proses Pencetakan, Pengukusan dan Pemotongan Nuget Kelinci

3) Topu Karage Kelinci

Cara membuat Topu Karage

- Isi tahu kering dengan pasta kelinci

- Gulung tahu isi pasta dengan tambahan campuran pelapis
- Kemudian celupkan ke air dan gulingkan dengan bahan pelapis, ulangi 2-3 kali.

- Kemudian goreng didalam minyak yang sudah dipanaskan diatas api yang matang

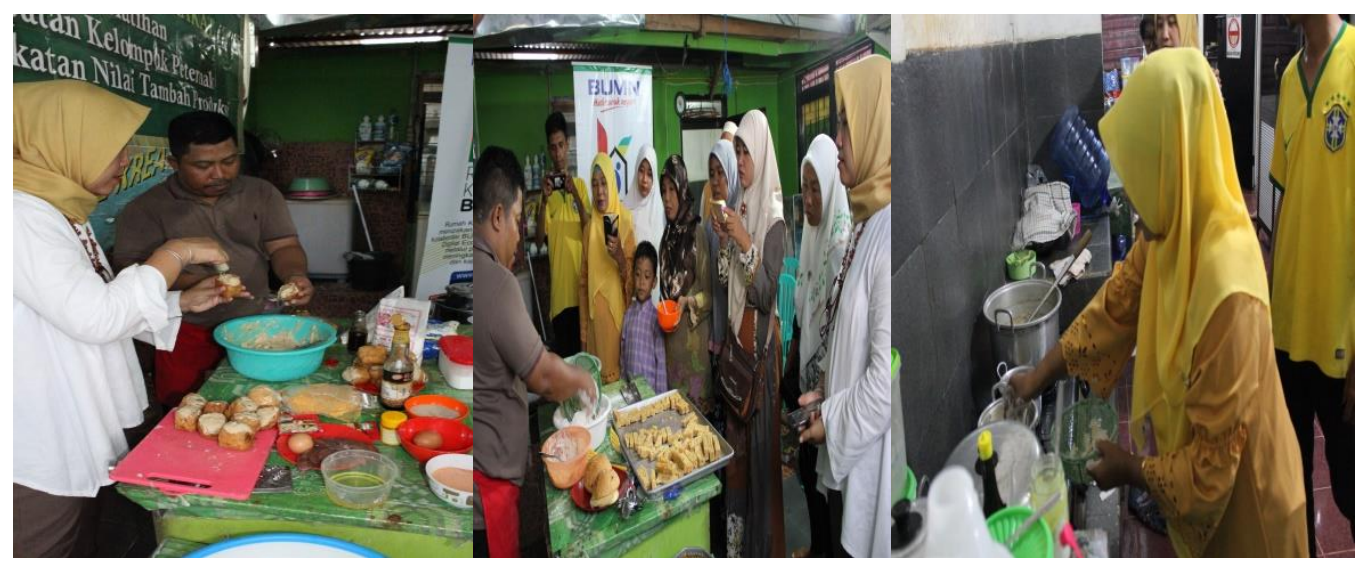

Gambar 6. Proses Pembuatan Topu Karage

4) Patty Burger Kelinci

Cara membuat burger :

- Campurkan semua bahan lalu aduk hingga rata

- Setelah tercampur rata. Bentuk menjadi bulat pipih dalam beberapa bagian.

- Kukus selama 10 menit
- Setelah selesai celupkan kedalam kocokan putih telur dan segera balurkan dengan tepung roti hingga rata, sambil di tekan perlahan. Ratakan pipihan adonan seperti membuat perkedel kentang. Sambil ditekan, kita ratakan dengan tepung roti. Sisihkan.

- Lakukan hingga selesai, setelah itu simpan di freezer selama 10 - 15 menit supaya set. 


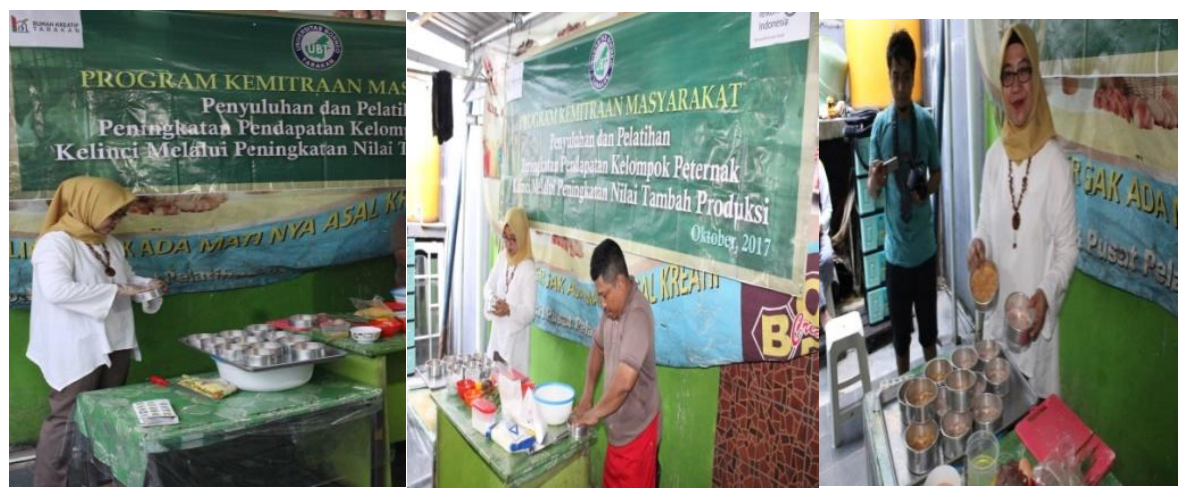

Gambar 7. Proses Pembuatan Patty Burger

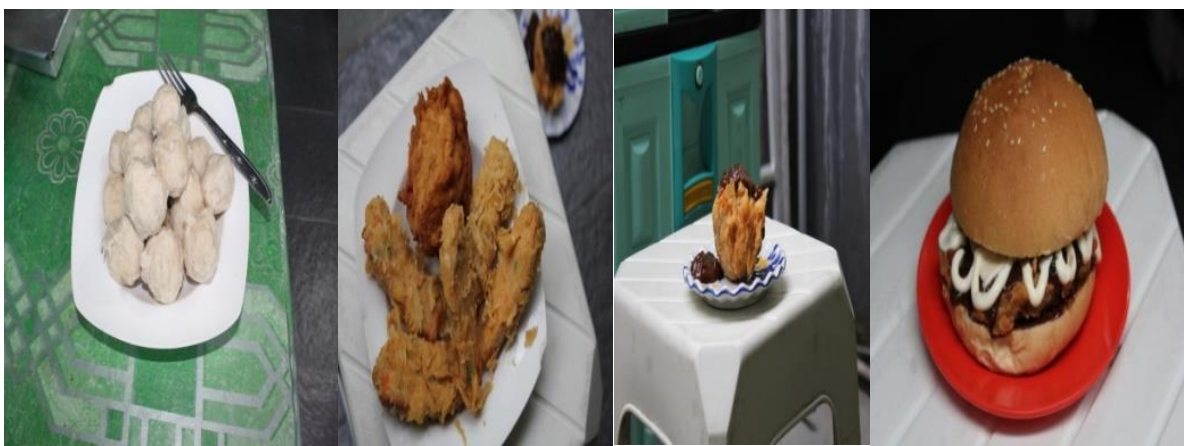

Gambar 8. Bakso Kelinci, Nuget, Topu Karage dan Burger Kelinci

5) Pupuk Organik

Cara membuat pupuk organik bahan

ditaburkan langsung kedalam media feses kelinci :

tanam

Cara membuat pupuk organic bahan urin

- Dicampur kotoran kelinci dan arang sekam dengan rata

kelinci :

- Larutkan tricodherma dalam $500 \mathrm{ml}$

- dicampur urin kelinci, EM4 dan molasi

- Siramkan larutan tersebut pada

- Dimaskan ke dalam wadah dan aduk campuran feses dan sekam dengan• merata secara merata

Letakan pada tempat yang terlindung• dari hujan

- Tutup dengan plastik hitam/terpal

- Biarkan selama 10-15 hari

- Pupuk organik feses kelenci siap kelinci (POC) siap diaplikasikan diaplikasikan ketanaman, dengan cara

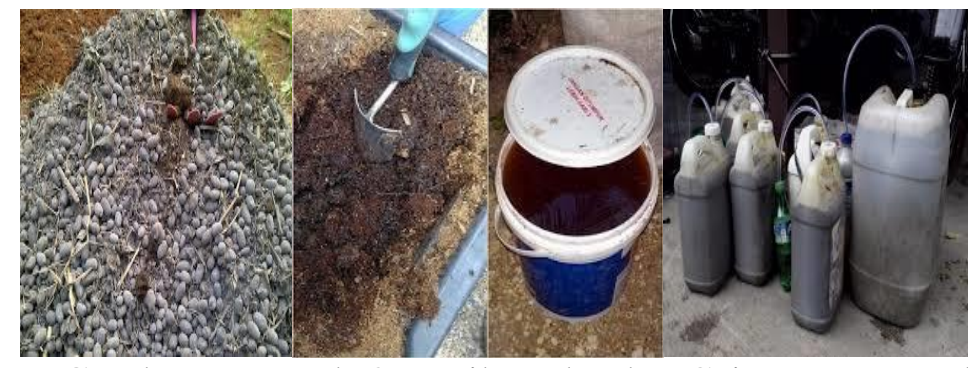

Gambar 9. Pupuk Organik Padat dan Cair Kotoran Kelinci. 


\section{Pendampingan}

Pendampingan dilakukan bersama penyuluh yang menjadi pembina kelompok Flora Mandiri dan Lady Valentine. Pendampingan menggunakan metode secara langsung dan tidak langsung. Pendampingan secara langsung dengan cara individu melalui kunjungan rumah dan kunjungan ke lokasi usaha dan secara kelompok melalui pertemuan dan diskusi, sementara pendampingan secara tidak langsung dilakukan dengan melalui media seperti telepon, dan media social.

\section{E. Hasil Kegiatan}

Hasil kegiatan penyuluhan dan pelatihan pengolahan daging dan kotoran kelinci dapat merubah perilaku sasaran baik aspek pengetahuan, keterampilan dan sikapnya, hal ini dapat terlihat dari yang semula tidak tahu menjadi tahu , tidak mampu menjadi mampu dan tadinya tidak mau menjadi mau mengolah daging kelinci menjadi beberapa produk makanan yang memberikan nilai tambah bagi usaha sasaran. Berdasarkan hasil wawancara dengan sasaran perubahan tersebut dapat dilihat pada table berikut.

Tabel 7. Perubahan Perilaku Peternak Kelinci dalam Memanfaatkan Daging dan Kotoran Kelinci.

\begin{tabular}{|r|r|r|r|r|r|r|}
\hline \multirow{2}{*}{ Materi } & \multicolumn{3}{|c|}{ Sebelum Penyuluhan dan Pelatihan } & \multicolumn{3}{|c|}{ Sesudah Penyuluhan dan Pelatihan } \\
\cline { 2 - 7 } & Pengetahuan & Keterampilan & Sikap & Pengetahuan & Keterampilan & Sikap \\
\hline $\begin{array}{r}\text { Membuat Bakso } \\
\text { Kelinci }\end{array}$ & - & - & - & $\sqrt{ }$ & $\sqrt{ }$ & $\sqrt{ }$ \\
\hline $\begin{array}{r}\text { Membuat Nuget } \\
\text { Membuat Topu } \\
\text { Karage }\end{array}$ & - & - & - & $\sqrt{ }$ & $\sqrt{ }$ \\
\hline $\begin{array}{r}\text { Membuat Burger } \\
\begin{array}{r}\text { Membuat pupuk } \\
\text { organik }\end{array}\end{array}$ & - & - & - & $\sqrt{ }$ & $\sqrt{ }$ \\
\hline
\end{tabular}

\section{(4) KESIMPULAN DAN SARAN} Kesimpulan :

1. Kelinci dapat dimanfaatkan baik daging maupun kotorannya.

2. Pengolahan daging kelinci dapat dijadikan beberapa jenis makanan seperti bakso kelinci, nuget, topu karage dan patty burger, selain itu kotorannya dapat dijadikan pupuk organic yang memberikan nilai tambah bagi ussaha ternak kelinci.

3. Melalui penyuluhan, pelatihan dan pendampingan dapat merubah perilaku peternak baik aspek pengetahuan, keterampilan dan sikapmya.

\section{Saran :}

Untuk dapat merubah perilaku peternak dalam usahanya diperlukan penyuluhan, pelatihan dan pendampingan yang berkelanjutan.

1. Harus ada sinergi antara Perguruan Tinggi dan pemerintah dalam meningkatkan usaha peternak kelinci di Kota Tarakan.

\section{DAFTAR PUSTAKA}

Amanah.S. 2007. Makna Penyuluhan dan Transformasi Prilaku Manusia. Jurnal Penyuluhan. Desember 2007 Vol 3 No 1, ISSN : 1858.2664.

Badan Pusat Statistik. 2014. Tarakan Dalam Angka Tahun 2014. Tarakan 